JFTH

Vol. 16, Issue 2 (2019)

ISSN: 2314-7024

E-ISSN: 2682-2180

\title{
Wet Nurse in art in Graeco-Roman Egypt
}

\section{Marwa Abd EIMeguid ElKady}

Associate Professor of Archaeology and Civilization of Egypt in Graeco-Roman

Period- Faculty of Tourism and Hotels Alexandria University.

\section{Manal Mahmoud Abd ElHamid}

Associate Professor of Archaeology and Civilization of Egypt in Graeco-Roman

Period- Faculty of Tourism and Hotels Alexandria University.

\section{Nermine Elsayed Mahmoud Gad}

Researcher in the Department of Tourist Guiding

Faculty of Tourism and Hotels, Alexandria University

\begin{abstract}
The wet nurse is a woman employed to breastfeed another woman's baby other than her own, for certain salary. This profession was very important to most of the ancient families in Egypt, especially in Pharaonic and GraecoRoman Egypt. Most of the information about wet nurses is sourced from the reliefs shown on the walls of the temples and tombs, minor art exhibited in the galleries of the different museums, and from the contracts mentioned in the ancient papyrus especially the Oxyrhynchus papyri. Wet nurse in Pharaonic Egypt has very essential role, either in divinity or in social society. She is very important for the king to insure his royal rights. Private wet nurses are also used among the upper classes; they are also depicted on the walls of tombs, showing signs of love to their owners. Many details were given about wet nurses and wet nursing as an important profession
\end{abstract}

in Egypt during the Greek and Roman times. This section of the study depends on contracts preserved in the ancient papyrus that provides us with a lot of information about this profession, also the physician Soranus was one of the most interested Greek doctor, who gives many details about wet nurses. The paper is supported by a catalogue of the representation of wet nurses in Greek and Roman Egyptian art. It deals with Divine Wet nurse in Greek and Roman Egypt, especially Hathor and Isis. The representations of divine wet nurses in temples' relief as Dendra, Edfu, Philae and Armant. And in minor art.

Key Words: Wet nurse, Divine wet nurse, Milk.

\section{Introduction}

Wet nurse is a woman employed to care, feed or breast-feed another woman's baby or an infant other than her own. It is widely accepted as a social custom for high 
and ruling classes Wealthy mothers, who do not wish to breastfeed their infant, pay married women to suckle them, either in the family home or, more usually in the nurse's home. Wet nurse had played an essential role in Egypt during the Greco-Roman period, as she was one of the strong solutions used by parents to suckle the baby whose mother died, or has any other physical or social problem.

In Pharaonic Egypt, the divine wet nurse was an important mean to confirm and prove the king's divinity. The first appearance of divine wet nurse in Pharaonic Egypt was in the fifth dynasty during the reign of the king Sahure (second king of the fifth dynasty). Royal wet nurses, occupy a great place in ancient Egypt, This was indicated by their tombs, built by kings as a desire to honor their royal nurses. Goddesses Isis and Hathor are the famous divine wet nurses depicted in Graeco-Roman Egyptian art. Reliefs from Egyptian temples show the two goddesses suckling their infant Horus in front of the king or the emperor, who is shown making offerings to the goddess. Museums all over the world preserved numerous statues of Isis suckling Horus the child, which indicates the importance of suckling and emphasizing the significance of the role divine wet nurse in ancient Egypt.

\section{General Overview about Wet Nurses}

Wet nursing began as early as 2000 B.C, and extended until the Twentieth century. Throughout this time period, wet nursing revolved from an alternative of need (2000 B.C), to an alternative of choice (950 B.C to1800 A.D) ${ }^{1}$.It was the oldest profession for women and it dated back at least 2000 years ago ${ }^{2}$.

\footnotetext{
${ }^{1}$ Emily Stevens and Thelma Patrick, "A History of Infant Feeding," JPE 18, 1(October 2009): 32.

${ }^{2}$ Prophecy Cloes, The Shadow of the second Mother: Nurses and Nannies in the theories of infant development (London: 2015), 2.
}

Many reasons lead mothers to use wet nurses. Physical reasons were the strongest specially mothers of poor health, another pregnancy ${ }^{3}$. In addition, using wet nurses became fashion for wives of the aristocracy and wealthy families ${ }^{4}$. Fashionable mothers were afraid of losing their good figure, the excitement of society ${ }^{5}$, as concerts ${ }^{6}$. Furthermore, Comfort and beauty consideration could also indicate the employment of wet nurses ${ }^{7}$. There were common beliefs that breastfeeding would affect the appearance of the breast ${ }^{8}$, making it sag, also suckling would make them fat, so their clothes wouldn't be suite for them and wouldnt be sold ${ }^{9}$.

Finally, the need for a woman's participation in the family economy ${ }^{1}$, Mothers go to work and send their babies to wet nurses ${ }^{2}$

There are three types of wet nurses. The first type is an is an icon showing the goddess nursing the king, representing him, by the act of nursing and suckling the king, the goddess confirms the king as her son, this type is called the divine wet nurse ${ }^{3}$. The second type was known as the royal wet nurse who was employed to breast feed the royal child of the king 4 . They were selected from the harem of senior officials of the royal palace and enjoyed a high status ${ }^{5}$. The last type of wet nurses is the un royal or private wet nurse, who breast feed the wealthy infant ${ }^{6}$.

\footnotetext{
${ }^{3}$ Sarah Franklin, Women and Slavery in Nineteenthcentury Colonial Cuba (New York, 2012) 140

${ }^{4}$ Gina Kolta, "Wet Nursing Boom," Science, New series 235(4790): 745.

${ }^{5}$ Bouth C.H.F., "The Disadvantages of Employing Fallen Women as Wet Nurses," BMJ, (April, 1860): 293.

6 Lionel Rose, The Massacre of The Innocents: Infanticide in Britain 1800- 1939(New York, 1986), 53. ${ }^{7}$ Angeliki Kosmopoulou, " Working Women: Female Professional on Classical Attic Gravestones, " ABSA 96 (2001): 285.

${ }^{8}$ Samir Arora and Cheryal Mcjunkin, " Major Factors Influencing Breastfeeding Rates: Mothers Perception of Father's Attitude and Milk Supply, "Pediatrics 106(5), (November, 2000): 67.

9 Gina Kolta, "Wet Nursing Boom, " Science, New series 235 (4790) : 746
} 


\section{Representations of Wet Nurse in Ancient Egyptian Art}

The job of wet nurse was expressed

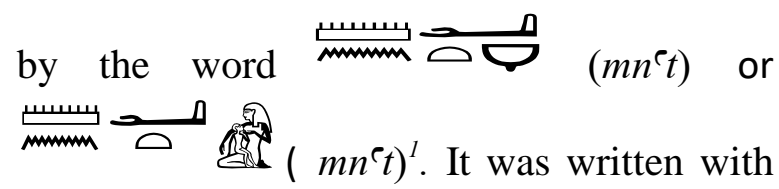

the determinative either breast $\square$ or woman suckling a child 2 .Wet nursing in ancient Egypt was one of the few well-paid jobs, which were open to women of all classes. Because of the high rates of mother's death during childbirth, wet nurse was always a profession in demand ${ }^{3}$. Ancient Egyptians women breasted their children for three years ${ }^{4}$, that is why poor and lower level women who could not hire a wet nurse, took their babies along with them everywhere even to work. In addition, they attended ceremonies, carrying their children on their sides or more usually on their back. A scene from the Theban tomb of Menna (TT69) ${ }^{5}$, dated to the nineteenth dynasty, located in the necropolis known as the tombs of the nobles in the ancient town of Thebes, now Luxor. The scene (fig.1) shows a peasant woman gathering the fruit of a tree while her baby is pulling her hair ${ }^{6}$.

\footnotetext{
${ }^{1}$ WBII, 78.

2 Carolyn Graves Brown, Dancing for Hathor: Women in Ancient Egypt ( London, 2010), 83

${ }^{3}$ Joycee Tyldesley, Daughters of Isis: Women of Ancient Egypt (London, 1995), 78.

${ }^{4}$ Joyce E. Salisbury, Encyclopedia of Women, 97, 98.

${ }^{5}$ Menna, a scribe and overseer of fields belonging to the Amun temple and a royal field scribe for upper and lower Egypt, from his titles overseer of fields of Amun (imy-r Ahwt $\mathrm{n}$ imn), overseer of plow lands of Amun (imy-r xbsw $\mathrm{n}$ imn; Melinda Harlwig, The Tomb Chapel of Menna (TT69) The Art, Culture and Science of Painting in an Egyptian Tomb ed. Melinda Harlwig (Cairo, 2013), 1, 16.

6 George Foucart, "Children (Egyptians)," in Encyclopedia of Religion and Ethics volume III ed. James Hastings (New York, 1910),533.
}

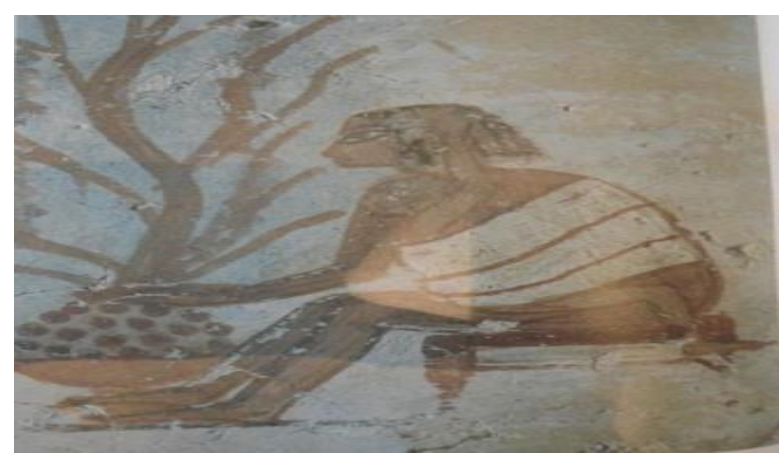

(fig.1)

Peasant woman gathering the fruit of a tree while holding her baby

Tomb of Menna TT69 (Sheikh Abd-Al Qurana)

Sigrid Hodel Hoenes, Life and Death in Ancient

Egypt Scenes from private tombs in New kingdom Thebes (London, 2000), fig.58

The mother and her child are seated on a stool under a tree. She has wrapped her dress around the child as a sling. 7 .

Divine wet nurse appears in the Egyptian iconography in the fifth dynasty during the reign of king Sahure (The second king of the fifth dynasty $)^{8}$. There is a scene represented on a large block found in the valley temple of the complex of Sahure at Abusir ${ }^{9}$ (fig.2). The scene represents the youthful king, with the goddess Nekhebet ${ }^{10}$ and the God Khnum $^{11}$. He holds the goddess' arm with his

\footnotetext{
${ }^{7}$ Sigrid Hodel Hoenes, Life and Death in Ancient Egypt Scenes from private tombs in New kingdom Thebes (London, 2000), 91.

${ }^{8}$ Stephanie Lynn Budin, Images of Woman and Child Reconsidering Fertility, Maternity, and Gender in the Ancient World (New York, 2011).

${ }^{9}$ Abusir, ${ }_{1} \sqrt{d}$ pr-wsir is a village west of the nile, about seventeen kilometers south of the pyramids of Giza, the name of the village is the Arabic rendering of the ancient Egyptian Per-Wesir, which means the "house of Osiris" for the greater part of the fifth dynasty royalty, L.E.S.E "Abusir," in Encyclopedia of the Archaeology of Ancient Egypt ed.Kathryn A. Bard (London, 1999), 97, 98, 99.

${ }^{10}$ Vulture goddess of the city of Elkab( on the east bank of the Nile, twenty miles of Esna). She was considered a maternal Goddess who protected the childbirth. Margret R. Bunson, Encyclopedia of Ancient Egypt (New York, 2002), 274.

${ }^{11}$ Was a divine craftsman, a builder of ferry boats and ladders. Khnum always portrayed as a ram or a ram
} 
right hand, while his left arm lowered along the body. The goddess Nekhebet is wearing her usual vulture headdress. She is suckling the king with her breast held with her hand ${ }^{1}$.

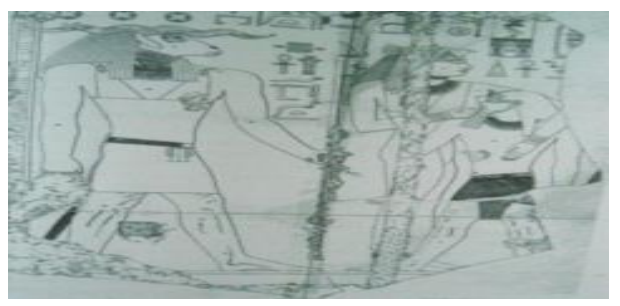

(fig.2)

King Sahure is shown suckled by the goddess Nekhbet

Fifth dynasty-valley temple of the complex of the king Sahure (Abusir)

Stephanie Lynn Budin, Images of Images of Woman and Child Reconsidering

Fertility, Maternity, and Gender in the Ancient World (New York, 2011), 30.

A Fragment from the hall of the funerary temple of Pepy I ( $2^{\text {nd }}$ king of the sixth dynasty), depicted the king being nursed by unknown Goddess $^{2}$ (fig.3). The Goddess's hand supports the breast ${ }^{3}$.

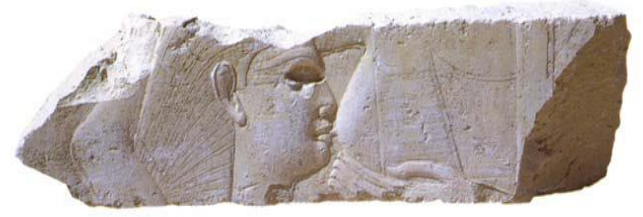

(fig.3)

Pepi I suckled by unknown goddess.

Sixth dynasty-funerary temple of Pepy I

headed man, in Theban story he is responsible for the creation of human beings on a potter's wheel, providing human health and wellbeing,; Glenns S. Holland, Gods in The Desert Religions of The Ancient Near East ( Maryland, 2009), 34.

${ }^{1}$ Andrzej Cwiek, "Relief Decorations in the Royal Funerary Complexes of the Old kingdom: Studies in the Development scene content and Iconography" (MA thesis, University of Warsaw, 2003), 177.

${ }^{2}$ Audran Labrousse, Les Pyramides Des Reines Une Nouvelle Necropole A Saqqara (Washington, 1999), 88.

${ }^{3}$ Andrzej Cwiek, "Relief Decorations in the Royal Funerary Complexes," 180.
Audran Labrousse, Les Pyramides Des

Reines Une Nouvelle Necropole A Saqqara

(Washington, 1999), 88.

The appearance of images depicting kings with divine wet nurses decrease in the Middle kingdom; this may be due to the decrease in women and queens' status. The depiction of the divine wet nurse wholly disappeared during the Middle kingdom except one known example from Upper Egypt site of Dendara ${ }^{4}$, where king built a small royal cult chapel for the Goddess Hathor ${ }^{5}$ At the upper Egyptian site of Dendera is located a chapel constructed in the reign of Nebhepetre - Mentuhotep, it stands now in the Egyptian museum of Cairo (JE46068) ${ }^{6}$. In the upper register of the chapel, to the left, a scene shows the king Nebhepetre - Mentuhotep before Hathor, she is suckling him ${ }^{7}$ (fig.4).

\footnotetext{
${ }^{4}$ Site of the ancient capital of the sixth upper Egyptian Nome. It was called in the ancient source (iwnt.t), in Greeek and Roman period, it known as(Tevtura), in Arabic language it known as Dendara. It is situated near Qena on the west bank of the Nile. Dendara necropolis dated from the early from the early dynastic period, to the first intermediate period. The temple of Hathor was the most famous monument in Dendara, it dated to the Greek and Roman period. .The main temple dated to the Ptolemaic and Roman period; Ian Shaw and Paul Nicholson, The British Museum Dictionary of Ancient Egypt (Cairo, 1995).; Sylvie Cauville, " Dendara," in Encyclopedia of the Archaeology of Ancient Egypt ed. Kathyrn a.Bard (London, 1999) : 252, 253.
}

${ }^{5}$ Stephanie Lynn Budin, Images of Woman, 55, 56 ; Hathor: Her name means "House of Horus", She was the Egyptian sky Goddess, Goddess of dancing, music and Love. She is always portrayed in the form of a cow or woman with a cow's ears., The Routledge Dictionary of Gods Goddess Devils and Demons (London, 1984):75.

${ }^{6}$ Stephanie Lynn Budin, Images of Woman, 56.

${ }^{7}$ Labib Habachi, " King Nebhepetre Menthuhotep : His Monuments, Place in History, Deification and Unusual Representation in the Forms of Gods, " MDAIK 19 (Kairo, 1963):27. 


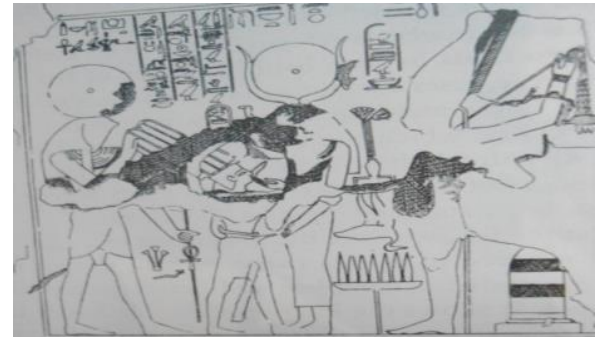

(fig.4)

The king Nebhepetre- Mentuhotep suckled by Hathor Egyptian museum in Cairo (JE46068)

Labib Habachi, " King Nebhepetre Menthuhotep : His Monuments, Place in History, Deification and Unusual Representation in the Forms of Gods, " MDAIK 19 (Kairo, 1963), fig.7.

From the beginning of the eighteenth dynasty, some goddesses and divine wet nurses were depicted in the form of tree with breasts. This scene was represented in the tomb of the king Thutmosis III $^{1}$ in the Valley of the Kings (KV 34) ${ }^{2}$ (fig.5). The scene represents Tuthmosis III, holding his staff and suckled at the breast of Isis who is in the form of Sycamore tree. ${ }^{3}$ The royal family of Thutmosis III was also represented in the scene, from the left to right, Nefertari B (daughter of Thutmosis III), Nebtu(wife of Thutmosis III), Sitiah(The great wife of Thutmosis III), Meryetre-Hatshepsut(great wife of Thutmosis III), and Thutmosis himself holding his Staff, behind him, a verticalhieroglyphic inscription as follow:

\footnotetext{
${ }^{1}$ Thutmosis III: He was the son of ThutmosisII and a secondary wife called Isis. He was still an infant when he became king on the death of his father. He ruled with Hatshepsut as co-regents. His famous battle was at Megiddo in Syria. He led the attack in gold and electrum chariot, leading one third of the army; Charlotte Booth, The Ancient Egyptians for Dummies (London, 2011), 69.

${ }^{2}$ Urs Winter, Frau Und Gottin: Exegetische Und Ikonographische Studien Zum Weiblichen Gottesbild im Alten Israel Und in Dessen Umwelt ( Fribourg, 1983):438,439.

${ }^{3}$ Sycamore tree in ancient Egypt often associated with the goddess Nut, Hathor, and Isis. It appears to provide the most significant portrayal of life giving tree in Ancient Egyptian culture; William R. Osborne, "The Tree of Life in Ancient Egypt and The Book of Proverbs," JANER 14 (June 2014): 117, 118.
}

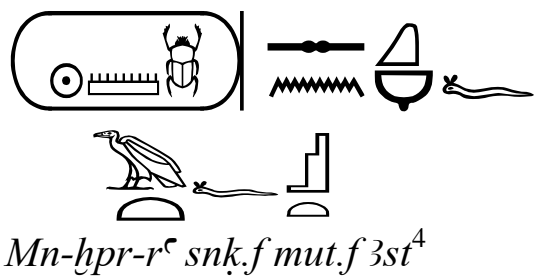

Menkheperra, his mother Isis suckles him ${ }^{5}$

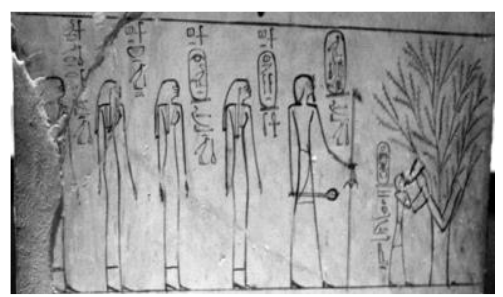

(fig.5)

Isis in the form of sycamore tree suckled thutmosis IV The tomb of the king Thutmosis III KV34(Valley of the Kings)

Aidan Dodson, " Thutmosis III: Family Man, " The Ostracon 15(2): 4 (fig.1).

An Eighteenth dynasty gold pendant dated to the reign of Tutankhamun and was found in his tomb (KV62) at Valley of the Kings (preserved now in the Egyptian museum in Cairo JE 61952) (fig.6). The pendant of Tutankhamun was found inside the small golden shrine in his tomb. The pendant takes the shape of the deity goddess Werethekau ${ }^{6}$ suckling Tutankhamun. The king is standing in front of the goddess whose body is in the shape of an upright cobra. She wears her bracelets, armlets,

\footnotetext{
${ }^{4}$ Aidan Dodson, " Thutmosis III: Family Man, " The Ostracon 15(2), ( Summer, 2004) : 4.

${ }^{5}$ Mohamed Abd Ellatef Hassan, "The Scenes of the Archaeological Objects of Suckling in Ancient Egypt from the Old Kingdom till the Greco-Roman Period" ( MA thesis, University of Alexandria, 2014):31.

${ }^{6}$ Wertt Hekau goddess, guardian of the pharaoh. Her name means " the great of magic", which as an epithet frequently follow the names of major goddess as, Hathor and Isis. Wertt Hekau appears in relief and inscriptions of the New Kingdom. She was depicted on the interior northern wall of the great hypostyle hall at Karnak as lioness goddess; George Hart, The Routledge Dictionary of Egyptian Gods and Goddess (London, 2005), 163.
} 
broad collar, earrings and a wig with vulture headdress, surmounted by a crown with two cow horns and a sun disc ${ }^{1}$.

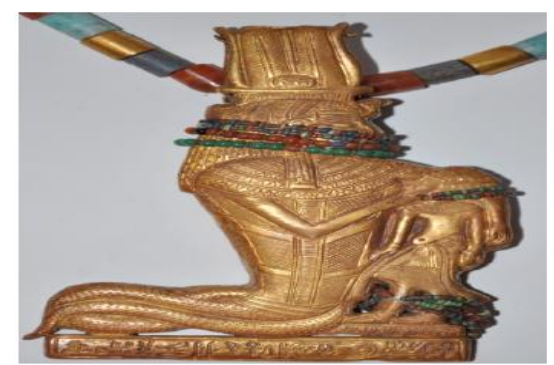

(fig.6)

Werethekau suckles Tutankhamun

Egyptian museum (Cairo) JE 61952

Ahmed M. Mekawy Ouda, "The Golden pendant of Tutankhamun) : 4.

From the Nineteenth dynasty, the king Seti I was the one who made the most visible use of the divine wet nurse motif. Most of these depictions come from his temple at Abydos ${ }^{2}$. In the second Hypostyle hall, a painted wall relief shows the seated goddess Mut in full gown and double crown with vulture headdress offering her breast with her left hand to Seti I who himself dressed in royal clothes(fig.7), and the blue crown. The goddess's right arm wrapped around the king's shoulders, and he holds the goddess's left wrist ${ }^{3}$.

\footnotetext{
${ }^{1}$ Ahmed M. Mekawy Ouda, "The Golden pendant of Tutankhamun ( JE. 61952). A new interpretation for the epithet Werethekau, " ENIM 9( Cairo, 2016) : 1, 4.

${ }^{2}$ Rosalie David, A Guide to Religious Ritual at Abydos (Warminster, 1981), 23.

${ }^{3}$ Stephanie Lynn Budin, Images of Woman, 77.
}

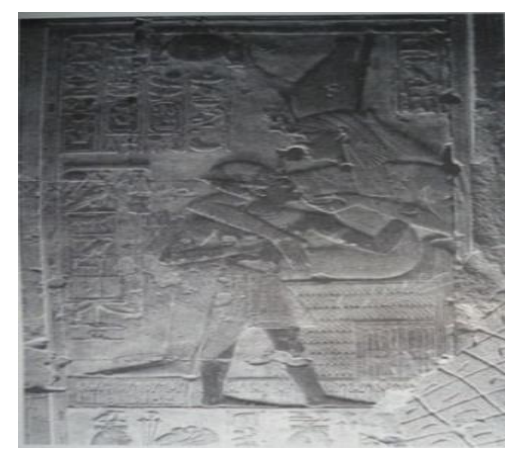

(fig.7)

Seti I suckled by Mut

Nineteenth dynasty- second Hypostyle hall temple of Seti I (Abydos)

Stephanie Lynn Budin, Images of Woman, 79.

The text inscribed behind the double crown of Mut:

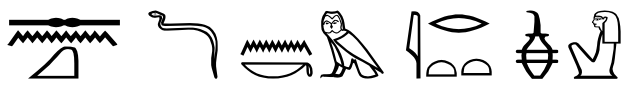

šnk n.k mitt.i

I suckled you with my milk ${ }^{4}$

Another depiction from the same temple were Seti I seated upon the lap of the divine nurse Isis (fig.8). Isis is sitting on the throne, she is wearing the cow - horned with solar disc, and uraeus, and vulture headdress. She holds the king's chin with her left hand and has her right arm wrapped around the young king's back ${ }^{5}$.

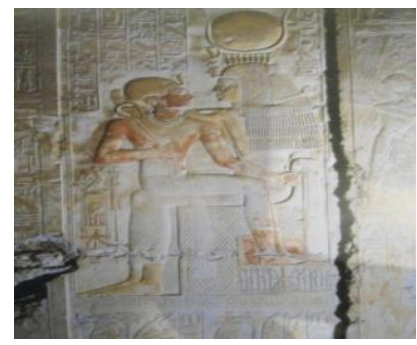

(fig.8)

Seti I is suckled by Isis Nineteenth dynasty-(temple of SetiI)

Nineteenth dynasty- (temple of Seti I) Abydos

Regine Schulz and Houring Sourouzian, "The Temples Royal Gods and Divine Kings," in Egypt the

\footnotetext{
${ }^{4}$ Mohamed Abd Ellatef Hassan, "The Scenes of the Archaeological Objects of Suckling", 45.

${ }^{5}$ Regine Schulz and Houring Sourouzian, "The Temples Royal Gods and Divine Kings," in Egypt the World of the Pharaohs ed. Regine Schulz and Matthias Seidel (Cairo, 2001): 209.
} 
World of the Pharaohs ed. Regine Schulz and Matthias Seidel (Cairo, 2001): 209

Royal wet nurses were also identified in ancient Egyptian art. They were selected from the harem of senior officials of the royal palace and enjoyed a high status. The earliest representation of Royal wet nurses is a statue of Hatshepsut seated on the lap of her wet nurse Sitre ${ }^{1}$ (fig.9). The statue discovered by the Metropolitan Museum Egyptian Expedition in Hatshepsut's temple at Deir El Bahari, preserved now in the Egyptian museum Cairo (JE 56264). The statue is life size statue of a woman sitting on a bench with miniature king seated on her $\operatorname{lap}^{2}$. The nurse is life sized, she sits at right angle. Her face was in a very bad condition, she is sitting holding the queen in the form of child on her knee ${ }^{3}$. The figure of Hatshepsut is preserved only from the hips down. She wears the pleated kilt as a king ${ }^{4}$.

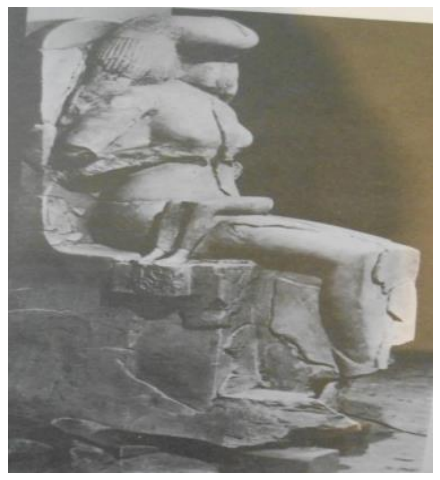

(fig.9)

\footnotetext{
${ }^{1}$ Cathrrine H. Roehrig, " Woman's Work: Some Occupations of Non Royal Women as depicted in Ancient Egyptian art, " in Mistress of the House Mistress of Heaven, 16.

${ }^{2}$ Catherine H. Roehrig, "Senenmut, Royal Tutor to Princess Neferure," in Hatshepsut From Queen to Pharoah ed. Catharine H. Roehrig ( London, 2005) $: 113$.

${ }^{3}$ Winlock, H. E. " The Museum's Excavation at Thebes, " BMMA 27( 3), (London, 1932) : 5.

${ }^{4}$ Catharine Roehring, " The Statue of the Royal Nurse Sitre With her Nursling MaaTkare Hatshepsut, " in Egyptian Museum Collection around The World ed. Mamodouh Eldamaty ( Cairo, 2000) : 1006.
}

Statue of the Royal wet nurse Sitre holding Hatshepsut Eighteenth dynasty- Egyptian museum(JE 56264).

Catharine Roehring, "The Statue of the Royal Nurse Sitre with

her Nursling Maatkare Hatshepsut, " in Egyptian Museum Collection around The World ed.Mamodouh Eldamaty ( Cairo, 2000) : 1009.

The royal nurse Amenopet appears in the tomb of her son Kenamun ${ }^{5}$,(TT93), (western Thebes) holding the pharaoh Amenhotep II on her lap $^{6}$ (fig.10). She is identified as $m n^{\complement} t$ wrt ny $n b$ t3wy "Great nurse and master of the two lands". The king is wearing the full royal regalia while; the nurse is shown holding the pharaoh on her lap ${ }^{7}$.

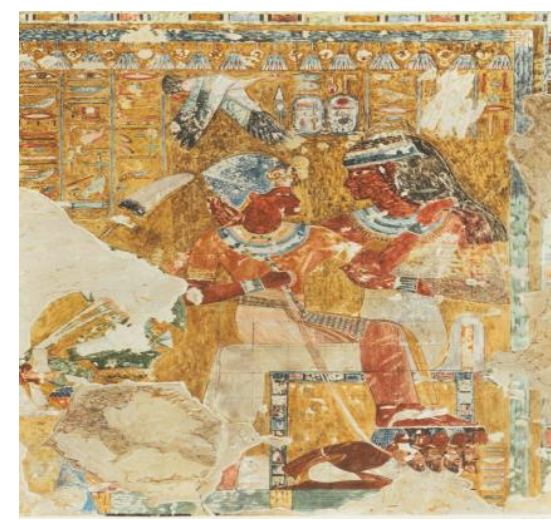

(fig.10)

Amenhotep II suckled by the royal wet nurse Amenopet

Eighteenth dynasty tomb Kenamun (TT93) - Thebes Norman De Garis, The Tomb Of Ken-Amun at Thebes Vol. II (New York, 1935), plate IX, A.

\footnotetext{
${ }^{5}$ Kenamun:Mayor of Thebes and overseer of the granary in the eighteenth dynasty. He helds his important office during the reign of AmenhotepIII. He was buried on the western shore of Thebes; Patrick E. MC Govern, Ancient Wine: The Search for the origins of Viniculture (New Jersey, 2003) , 127; Margret R. Bunson, Encyclopedia of Ancient Egypt, 196.

${ }^{6}$ Prisse D'Avennes, Atlas of Egyptian Art (Cairo, 2007), 115.

${ }^{7}$ Cathrrine H. Roehrig, "Woman's Work," in Mistress Mistress of the House Mistress of Heaven, 18.
} 
On the wall of the first chamber of the tomb of Tutankhamun's in the Memphite necropolis of Saqqara(fig.11), his wet nurse Maia is shown with the king on her lap ${ }^{1}$. He is looking to his right side facing his wet nurse; while, she is touching with her left hand the mouth of the king. ${ }^{2}$.

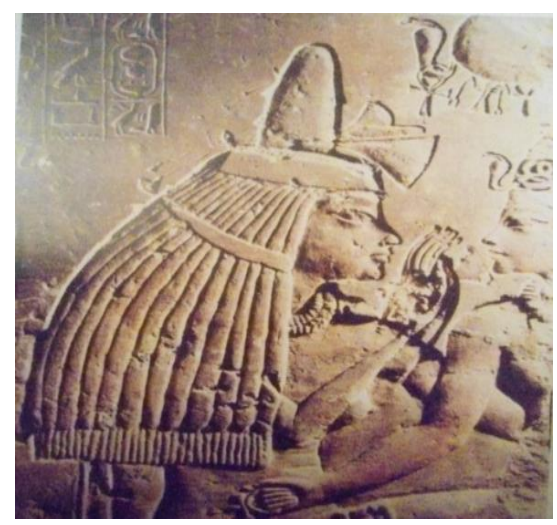

(fig.11)

Tutankhamun with his wet nurse Maia Eighteenth dynasty tomb Maia Saqqara

زاهى حواس ، سيدة العالم القديم ، دار الثروق، القاهره ، $1 \%$.

Wet nurses of private persons appeared on tombs walls or stalae. They probably also participate in the upbringing of the child ${ }^{3}$. From the Old kingdom, a lime stone figurine found in the serdab of $\mathrm{Ne}$ inpw-kauw and now in the Metropolitan Museum (26.7.1405), depicts a seated woman with two children (fig.12), on suckles at her left breast, while the second kneels behind the woman ${ }^{4}$.

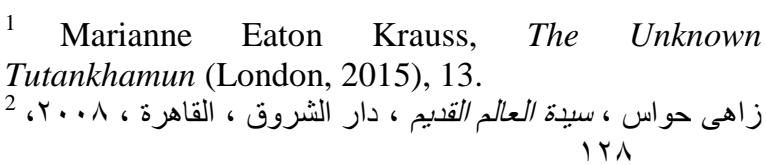

${ }^{3}$ Erika Feucht, "Women," in The Egyptians ed. Sergio Sergio Dona Doni, (Chicago, 1997): 329.

${ }^{4}$ William Stevenson Smith, A History of Egyptian Sculpture and Paintings, 101, 102

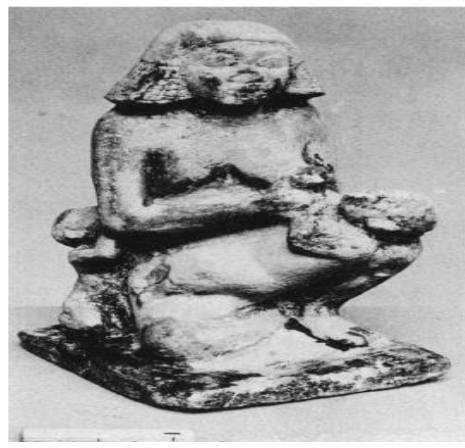

(fig.12)

Woman suckled a baby from the serdab of Ne-inpwkauw

Old Kingdom- Metropolitan Museum (26.7.1405) William Stevenson Smith, A History of Egyptian Sculpture and Paintings, plate27 (d).

\section{Names and Titles and selection of Wet Nurse in Greek and Roman Egypt}

Several terms were used to

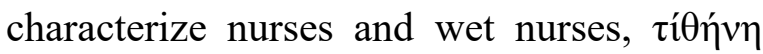
$\tau i \tau \theta \eta$ and $\tau \rho o \varphi o ́ s$ being the commonest ${ }^{5}$.Physician Soranus, who wrote in the early second century, was the best one who talked about the selection of good wet nurse $^{6}$. Soranus goes into great detail about the preferred body type of wet nurse ${ }^{7}$. For instance, medium sized breasts ${ }^{8}$, large frame ${ }^{9}$, equally formed breasts with neither nipples too large, nor too small nipples. They should left the milk flow out in a steady stream ${ }^{10}$. In addition, wet nurse's milk should be examined carefully, before starting

\footnotetext{
${ }^{5}$ Angeliki Kosmopoulou, " Working Women: Female Female Professional on Classical Attic Gravestones, " ABSA 96 (November, 2001) : 285.

${ }^{6}$ Aline Rouselle, Porneia : On Desire and the Body in in Antiquity ( Eugene, 1983), 56.

${ }^{7}$ Annette Bourland Huizenge, Moral Education for Women in the Pastoral and Pythagorean Letters (Boston, 2013), 18.

8 John G. Raffensperger, Children Surgery a World Wide History (North Carolina, 2012), 40.

9 Julia L. Hairston, " The Economics of Milk and Blood in Alberti's Libri della famiglia: Maternal Versus Wet Nursing, " in Medieval and Renaissance Lactation ed. Jutta Gisela (London, 2013), 190.

${ }^{10}$ Henry E. Sigerist, A History of Medicine: Early Greek, Hindu, and Persian, Volume II (New York, 1961), 233.
} 
feeding the baby ${ }^{1}$. Qualities of wet nurses' milk, was mentioned in the wet nursing contracts from Ptolemaic and Roman Egypt, a papyri dated to the fifth century B.C (Michigan papyri, Papyri russischer und georgischer Sammlungen, Sammelbuch griechischer Urkunden aus Ägypten), mentioned the features of wet nurse's milk:

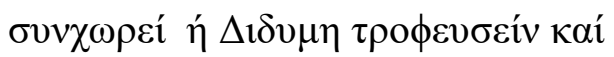

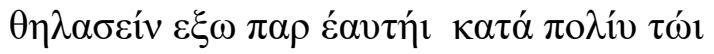

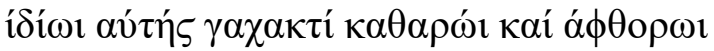
Didomy agreed to nurse outside (at her own home, in the city), with her milk, the pure, not rotten, not stinking. ${ }^{2}$

In case the mother cannot nurse her child, the next best way of feeding is to obtain a good wet nurse, if wet nurses could not be obtained, hand feeding becomes necessary ${ }^{3}$. From the reign of Thutmose III to early in the reign of Amenhotep III, several pottery vessels were manufactured in the shape of nursing mothers or wet nurses ${ }^{4}$. Theses jars took many forms as, kneeling woman with a child on Her back (fig.13), kneeling woman Suckling a child (fig.14), Standing Woman with two Holes from the two Nipples (fig.15), with Rare Feeding bottle dated to the Roman period (fig.16) and child feeding bottle (Early Ptolemaic period) Egypt(fig.17).

\footnotetext{
${ }^{1}$ Harry W. Paul, Henri de Rothschild 1872- 1947 Medicine and Theater (Florida, 2011), 120 .

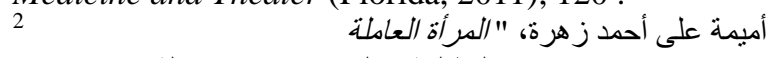

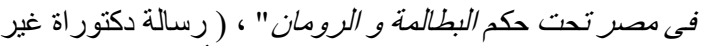

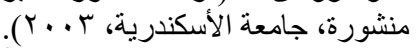

${ }^{3}$ Charles J. Culling Worth, The Nurse's Companion. A Manual of General and Monthly Nursing ( London, 1876), 109

${ }^{4}$ Carolyn Graves Brown, Dancing for Hathor, 67.
}

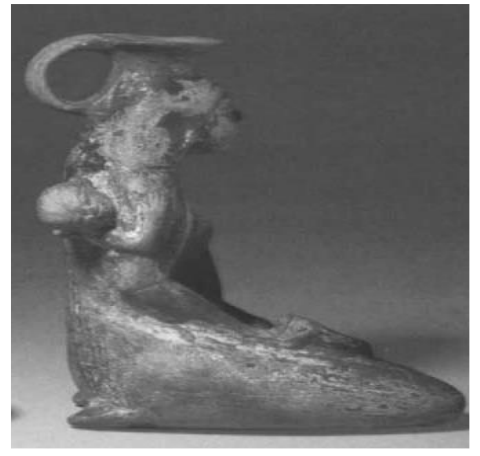

(fig.13)

Feeding flask in the form of kneeling woman with a child sprawled frog like against her back, the whole child is represented. British Museum (BM.26652).

Catharine H. Roherig, "The Two Tombs of

Hatshepsut, " in Hatshepsut From Queen to Pharaoh ed. Catharine H. Roehrig (London, 2005) : 233.

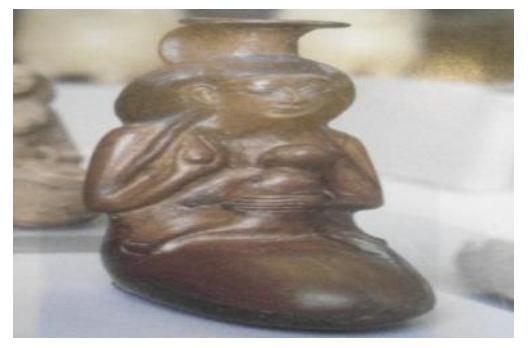

(fig.14)

Feeding flask in the form of kneeling woman suckling a child

Louvre museum (N.969)

Jan Quaegebeur, La naine et le bouquetin, ou, L'énigme de la barque en albâtre de Toutankhmamon (California, 2009), 34.

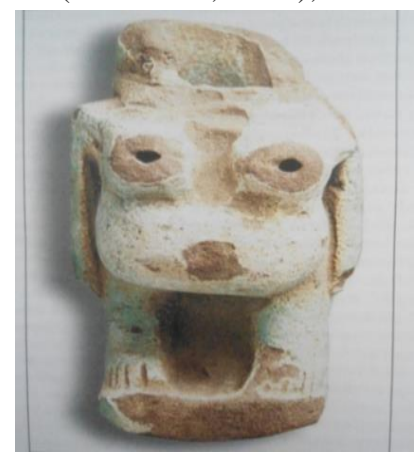

(fig.15)

Feeding Bottles in the form of standing woman with two holes from the two nipples.

The Rosicrucian Egyptian Museum

Bruno Halooua, Medicine in The Days of The Pharaohs (Cambridge, 2005), 80 


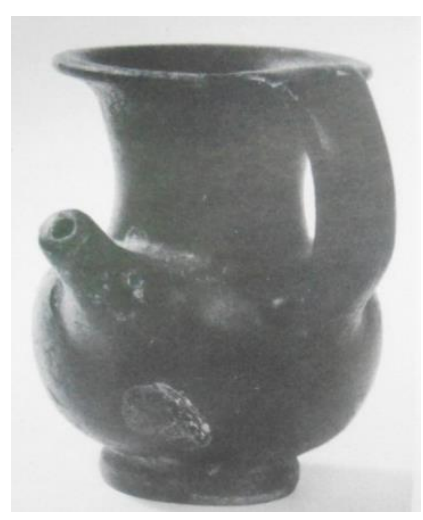

(fig.16)

Rare feeding bottle dated to the Roman period University of Queensland Antiquities Museum (inv.73/6)

Suzanna Dixon, The Roman Mother (London, 1988), plate 10.

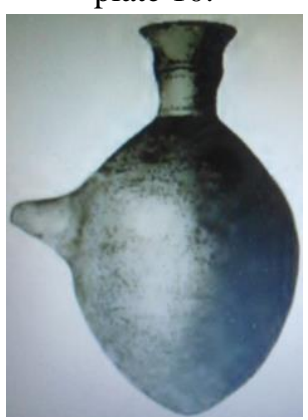

(fig.17)

Child sucking bottle (Early Ptolemaic period) Egypt Egyptian Museum- Cairo

Arthur F. Abt and Fielding Hudson, History of Pediatrics (New York, 1923), 16.

\section{Regulations Followed by wet nurses}

Wet nurses must follow many regulations and rules. Sexual Regulations of wet nurses were mentioned in the papyri (B.G.U) IV no.1107, dating to the year thirteen B.C.

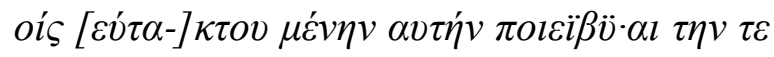

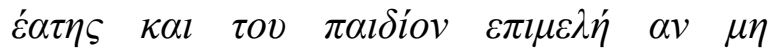

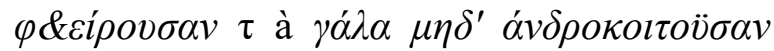
$\mu \eta \delta^{\prime} \varepsilon \pi \iota \kappa v ́ o v \sigma \alpha v$."So long as she is duly paid she shall take proper care both of herself and of the child, not injuring her milk nor sleeping with a man nor becoming pregnant" ${ }^{1}$.Furthermore, drinking wine regulations were also mentioned by Soranus, as stop using drugs, alcohol and wine ${ }^{2}$. They harmed the body of the wet nurse and so the milk was spoiled ${ }^{3}$.Nutrition regulations were also mentioned. The wet nurse should eat simple, good food in moderate quantity, as lamb, capon, hen, chicken, partridge, and veal and mixed egg with yolk ${ }^{4}$. Preserved Roman contracts from Egypt, mentioned legal regulations related to wet nurses, for example, if the child died while it was in the keeping of a wet nurse, she must return the salary she owed to suckle the baby ${ }^{5}$. Soranus mentioned the importance of daily outdoor exercise to wet nurses ${ }^{6}$. Open air was one of the reasons that give a good supply of health milk ${ }^{7}$.

\section{Wages of Wet Nurse in Greek and Roman Egypt}

The salary of wet nurse was also mentioned in a private account (dated to the fourth century A.D), the private account was given by an agent to his mistress who was absent in Alexandria, the account includes the paying out for the house hold and property, recording the salary of the wet

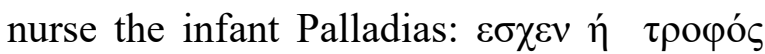

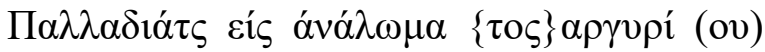

\footnotetext{
1 Keth R. Bradley "Sexual Regulations in Wet Nursing Contracts From Roman Egypt," KLIO 62(2), (February, 1980): 321.

2 Gerald G, Briggs, Drugs in Pregnancy and Lactation: A Reference Guide to Fetal and Neonatal Risk (New York, 2001), 17.

${ }^{3}$ Soranus, Gynecology, Book II (Baltimore, 1956), 93.

${ }^{4}$ Melitta Weiss Adamson, "Baby food in the Middle Ages," in Nurture: Proceeding of the Oxford Symposium on Food ed. Richard Hosking (Bristol, 2004),2.

${ }^{5}$ P.Oxy. I. 37 (49 A.D),79, 80.

${ }^{6}$ Alida Frances, Practical Dietetics with Reference to to Diet in Disease (New York, 1895), 718.

7 Thomas Bull, The Maternal Management of Children in Health and Disease (London, 1840), 33.
} 
( $\tau \alpha \lambda) \alpha, \ldots$ ( The nurse of Palladias had given service 1 tal. of silver) ${ }^{1}$

\section{Divine Wet nurses (Isis lactons and Hathor) in Greek and Roman Egypt}

The two goddesses, Hathor and Isis, almost played the same role as divine wet nurses to the Pharaohs and kings. Their iconography was similar, both are crowned with horns andsolar disc. Hathor and Isis were present in each other's temples ${ }^{2}$.The most popular presentment of Isis during the late period of the Egyptian history, was a mother suckling her infant, its popularity extended throughout the Greek and Roman periods ${ }^{3}$.Isis lactons, was the most famous figure representing Isis in Ptolemaic and Roman Egypt, Isis is depicted suckling her child in more than one form ${ }^{4}$.For instance, Isis Lactons on the Handles of Lamps A terracotta lamp (fig.18) dated to the first or second century A.D, discovered in Egypt (unknown province), preserved now in the National Museum (Athens, collection Benaki) No.782 MII. She is nursing Harpocrate over the handle of a lamp. Isis is sitting frontally, touching her left breast with her right hand to offer it to Harpocrate mother 5 .

${ }^{1}$ P.Oxy. X. 1288 (fourth century A.D), 239, 240.

${ }^{2}$ Detraci Regula, The Mysteries of Isis: Her Worship and Magic (London, 2001), 139.

${ }^{3}$ William Matthew, Ancient Egypt (Michigan, 1932), 51.

عبد الحميد عبد الحميد المرسى مسعود، "الأعمال الفنبة الخشبية فى 4

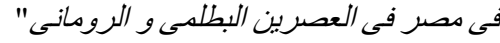

( رسالة دكتور اة غير منشورة، جامعة عين شمس، ( • ب) ، ص .

5 Tran Tam Tinh, Isis Lactons Corpus des Monuments Monuments Greco-Romains d'Isis allaitant Harpocrate ( Nether land, 1973), 79

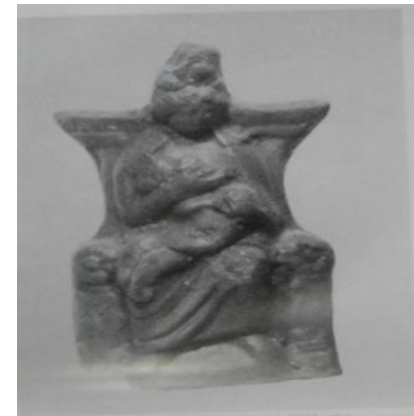

(fig.18)

Terracotta handle of lamp representing Isis lactons National Museum (Athens, collection Benaki) No.782 MII

Tran Tam Tinh, Isis Lactons Corpus des Monuments Greco-Romains d'Isis allaitant Harpocrate (Nether land, 1973), Planche XXXVI, No. (59-a).

The second form, Isis Lactons Growing from the Acanthus ${ }^{6}$ leaves, a terracotta lamp handle (fig.19), discovered in Egypt (unknown province), preserved now in the Museum of University of Tubingen, No.4888/25 The lamp handle takes the shape of Isis lactons, growing from the jagged blades of the Acanthus leaves. She holds her baby with her left arm, while holding her left breast with her right hand. Harpocrate is depicted naked ${ }^{7}$.

\footnotetext{
${ }^{6}$ A leaf motif used extensively on Greek and Roman sculpture. The design and name are taken from a prickly Herbaceous plant that is still wide spread in the Mediterranean area. Acanthus leaves are seen most frequently in architectural decoration, especially on the capitals of Corinthian colums. They are commonly seen in the design of the crowning elements of grave markers; Janet Burnett Grossman, Looking at Greek and Roman Sculpture in Stone: A Guide to Terms, Styles, and Techniques (Los Angeles, 2003), Glossary 1.

${ }^{7}$ Jutta Fisher, Griechisch-römische Terrakotten aus Ägypten (Tubingen, 1997), 343.
} 


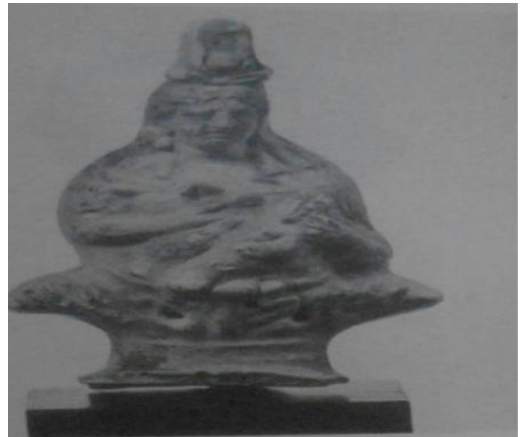

(fig.19)

Terracotta handle of lamp representing Isis suckling horus over Acanthus leaves

Museum of University of TubingenNo.4888/25Jutta Fisher, Griechisch-römische Terrakotten aus Ägypten , Tafel 89 (Nr.850)

Another form of Isis lactons, depicted on medallions, A good example of her is a bust statuette of Isis nursing Horus (preserved now in British museum EA1938.3.014.1), decorated a medallion (fig.20). The bust is dated to the Roman period. Isis is represented from the front. She raises her left breast with her right hand to offer it to Harpocrate, who is supported by his mother's left hand ${ }^{1}$.

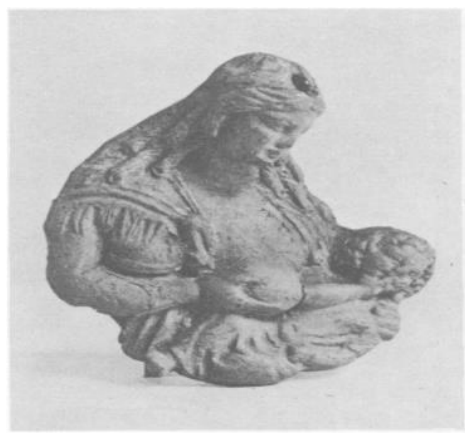

(fig.20)

A bust statuette of Isis nursing Horus, decorated a medallion (Roman period)

The British Museum EA 1938.3.14.1

G. D. Hornblower, " Predynastic Figures of Women and Their Successors, " JEA 15, 112 ( May, 1929), plate $\mathrm{X}(1)$.

Finally, rare example of Isis Lactons preparing to nurse Harpocrate while Standing. It is a statue that shows Isis

\footnotetext{
${ }^{1}$ Hornblower, G. D, "Predynastic Figures of Women and Their Successors," JEA 15 (112), (May 1929), 44.
}

depicted as a standing young woman (fig.21), She is holding a child with the same characteristics of Harpocrate, with her left arm, while holding her dress with her right hand. The child pulls the left breast of his mother ${ }^{2}$.

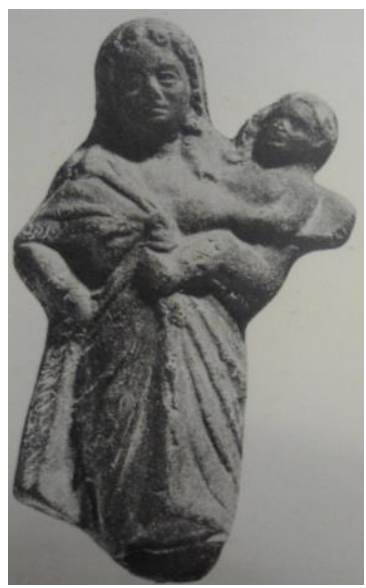

(fig.21)

Standing Isis Lactons

László Török, Hellenistic and Roman

Terracotta from Egypt (Roma, 1914), pl. LVI.

\section{Examples of the Representation of Divine Wet Nurses from the temple of Dendara}

Most of Ptolemaic and Roman temples contain a Mammisi ${ }^{3}$, in which the divine birth of the goddess' child was celebrated. ${ }^{4}$. The temple of Hathor at Dendara includes two Mammisis, one dating to the Roman period and the other dated to the time of Nectanebo I ${ }^{5}$. The Mammisi of

\footnotetext{
${ }^{2}$ Paul Graindor, Terres cuites de l'Egypte grécoromaine (Belgique, 1939), 97, 98.

${ }^{3}$ An invented Coptic word meaning ( Birth House), Mmmisi is a free standing building, where the annual rites associated with the birth of the God- king were performed, also the celebration rituals of the delivery of Goddesses Isis and Hathor: Rosalie E.David, $A$ Biographical Dictionary of Ancient Egypt( London, 1992) , XV; John F. Nunn, Ancient Egyptian Medicine( Oklahoma, 2002), 102.

${ }^{4}$ Barbara S. Lesko, The Great Goddess of Egypt, 227.

${ }^{5}$ The founder of the thirtyth dynasty, he came from the town of Sebennutos( ancient city of lower Egypt, locates on the Damietta branch of the Nile in the Delta). Nectanebo I, has a lot of buildings activities
} 
Nectanebo consists of a sanctuary, built by Nectanebo I, and an offering hall built by Ptolrmy II (Philadelphus). The Entrance of the offering hall bears two scenes on every side of the entrance ${ }^{1}$. The goddess Isis is depicted suckling her infant Ihy on the left scene ${ }^{2}$ (fig.22-A). Isis is wearing a long tight robe. On her head, she wears the horned crown with the sun disk. Her right arm is twisted around her infant Ihy, while she suckles her child with her left hand. Ihy stands in front of his mother naked. Goddess Hathor is depicted on the right side of the entrance (fig.22-B). She is twisting her left hand around Ihy, while suckling him with her right hand. Ihy is standing naked; he touches with his right hand ${ }^{3}$.

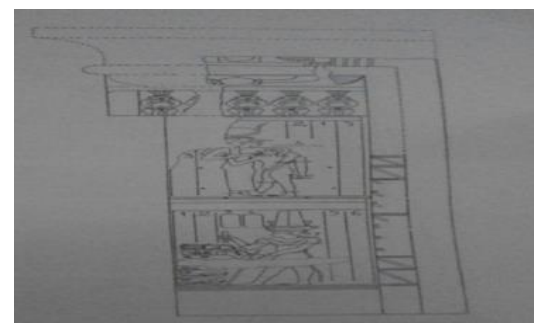

(fig.22-A)

Isis is suckling her infant Ihy

and monu

stability; F

89. Mic

(London,

${ }^{1}$ The Dwarf god, with a frightening appearance and a kind nature. Bes was a god of the people. He makes evils go away from families, bringing good luck to people, Pat Remler, The Egyptian Mythology A to Z, 29.

${ }^{2}$ A minor god worshipped in upper Egypt, he was the son of Hathor and Horus of Edfu. He is shown as a child with side lock of hair and a finger to his mouth; The Egyptian Mythology A to Z, 92.

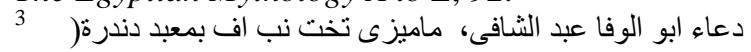

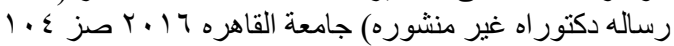

(fig.22-B)

Hathor is suckling her infant

Left and right of entrance of the offering hall (Mammisi of Nectanebo)-Dendara

\section{Francois Daumas, Les Mammisis de \\ Dendara ( Le Caire, 1959), pl.V}

$$
\text { (A).pl.V(B). }
$$

The Mammisi of Nectanebo I, has two other important scenes on the entrance of the sanctuary (dated to the reign of Ptolemy X). The first scene (fig.23 -A, 23$\mathrm{B})$, on the right lower part of the sanctuary, is a representation of the king Ptolemy $\mathrm{X}$, offering two flasks of milk to the goddess Hathor, in the form of Cleopatra who is depicted suckling her infant ${ }^{4}$.

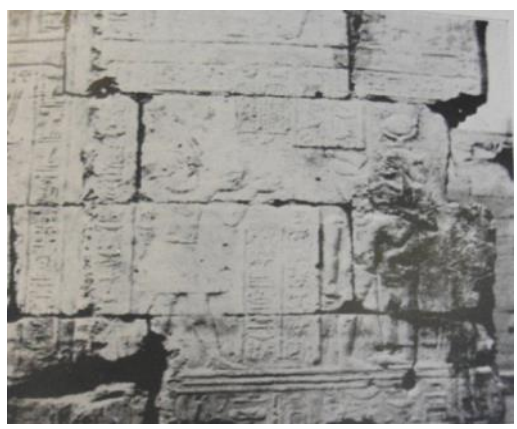

(fig.23-A)

Hathor is suckling Ihy

Right lower part (The Mammisi of

Nectanebo I)

Francois Daumas,

"La Structure de mammisi de Nectanebo a Dendara, " $B I F A O$ (Caire, 1950) , pl. XI(1).

\footnotetext{
${ }^{4}$ Francois Daumas, " La Structure de mammisi de Nectanebo a Dendara, " BIFAO L (le caire, 1950): 128.
} 


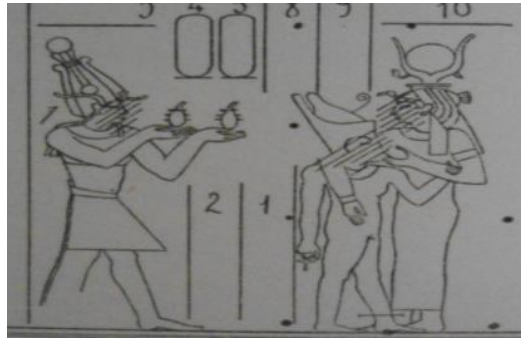

(fig.23-B)

Hathor is suckling Horus

Right lower part (sanctuary Mammisi of Nectanebo)Dendara

Francois Daumas, Les Mammisis de Dendara, Pl.VIII.

The second scene (fig.24 -A, 24-B), on the left lower part of the sanctuary, this scene is similar to the first one, the king is also depicted offering two flasks of milk to Hathor, who is represented suckling her infant ${ }^{1}$.

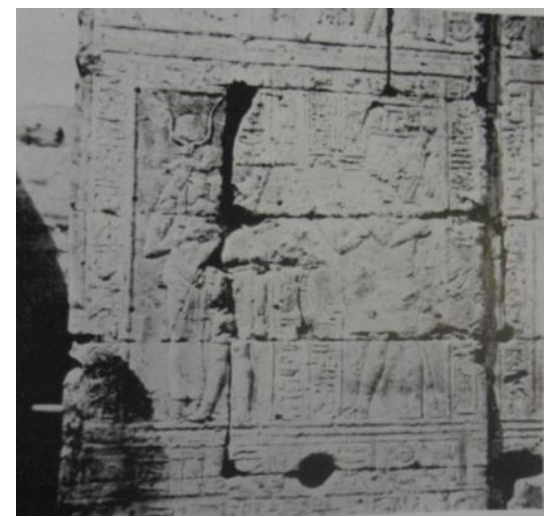

(fig.24 -A)

Hathor is suckling her infant

Left lower part (sanctuary Mammisi of Nectanebo)Dendara

Francois Daumas, " La Structure de mammisi de Nectanebo a Dendara, " BIFAO

(Caire, 1950), Pl. XI(2)

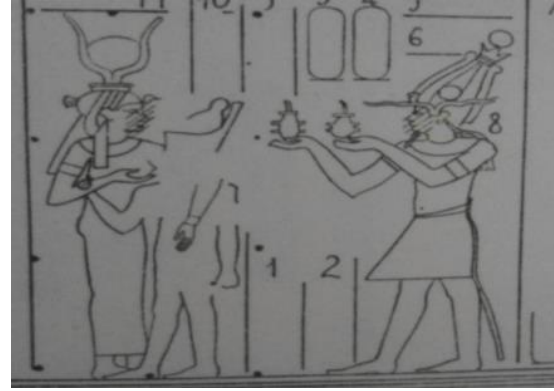

(fig.24 -B)

Hathor is suckling her infant

Left lower part (sanctuary Mammisi of Nectanebo)-

Dendara

Francois Daumas, Les Mammisis de Dendara, pl.VIII

The Roman mammisi at Dendera(built by Augustus and decorated by Trajan and Hadrian) ${ }^{2}$, has many scenes of Trajan making offerings to gods suckling their children ${ }^{3}$. There are two sunken relief of offering scenes on the outer walls of the mammisi of Trajan, in the first scene (fig.25), Trajan is represented making offering to Hathor, who is represented in the form of Cleopatra suckling her child Ihy ${ }^{4}$, with a second Ihy behind ${ }^{5}$.

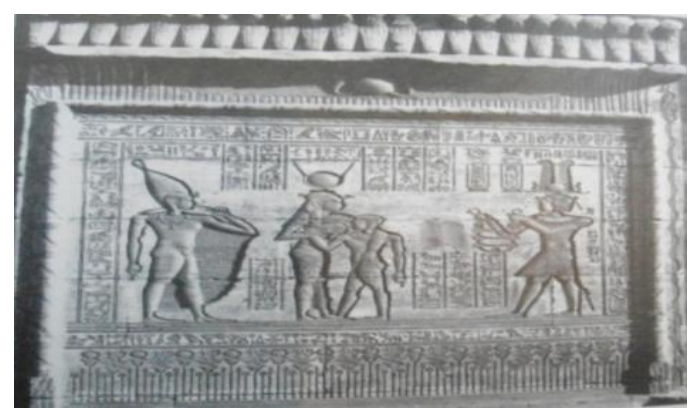

(fig.25)

Hathor is suckling Ihy

Outré walls of the Roman mammisi of Trajan(Dendara)

Sylvie Cauville, Le Temple de Dendera (Le Caire, 1990), 96

2 Kathryn. A. Bard, An Introduction to the Archaeology of Ancient Egypt (Florence, 2015) , 327. ${ }^{3}$ Frederck Brenk," Religion Under Trajan Plutarch, Resurrection of Osiris," in Sage and Emperor Plutarch, Greek Intellectuals and the Roman Power in the time of Trajan (98- 117 A.D) ed, Philip A. Stadter (Leuven, 2002) : 75.

${ }^{4}$ Sylvie Cauville, Le Temple de Dendera (Le Caire, 1990), 95.

5 John Baines and Jaromir Malek, Cultural Atlas of Ancient Egypt (New York, 2000), 113. 


\section{Examples of the Representation of Divine Wet Nurse from the temple of Edfu ${ }^{1}$}

The Mammisi of Edfu, has a lot of scenes representing the divine wet nurses Hathor and Isis, suckling their child Horus ${ }^{2}$. It takes a rectangular shape, consisting of a sanctuary with a pillared gallery, and an open court ${ }^{3}$.A scene depicted on the left side of the open court shows (fig.26), the king ptolemy X( AlexanderI), wearing the short kilt with the bull tail. He is offering flowers to the God Horus standing in front of him. Horus is wearing the double crown of upper and Lower Egypt. He is holding the enh sign in his right hand and the scepter in his left hand. Behind Horus, the goddess Hathor is standing suckling her child Horus $s m 3 t 3 w y$ (Horus the unifier of the two lands) ${ }^{4}$.

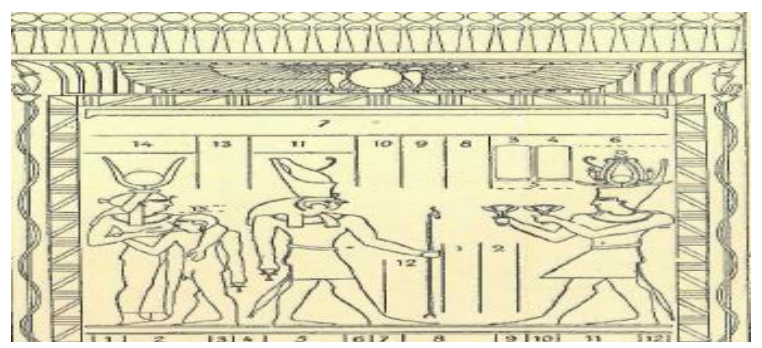

(fig.26)

Hathour is suckling Horus

Left wall of the open court( Mammisi of Edfu)

Emile Chassinant, " Le Mammisi D' Edfou," MIFAO 16 (le Caire, 1939) , pl.XLIX(4)
1 Edfu: i s known as $\approx$ (bhd.t), an upper Egyptian site and the capital of the second Nome in Upper Egypt. It was famous by its temple of Horus, which was built during the Ptolemaic period. The temple consists of , a massive pylon, court yard, first hypostyle hall, inner sanctuary with two hypostyle halls, inner shrine with original naos, and a mammisi; WB I, 470; Gwendolyn Leick, A Dictionary of Ancient Near Eastern Architecture ( London, 2002), 68; Ian Shaw and Paul Nicholson, The British Museum Dictionary, 89

${ }^{2}$ Zahi Hawas, Wonders of the Horus Temple The Sound and Light of Edfu (Cairo, 2010), 14.

${ }^{3}$ Arthur.E.P.Weigall, A Guide to the Antiquities of Upper Egypt: From Abydos to the Sudan Frontier (London, 1910), 346.

\footnotetext{
أشرف نادى احمد حسن، " الأمومة فى مناظر و تماثثيل الملوك و 4 و 4

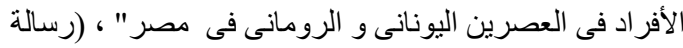

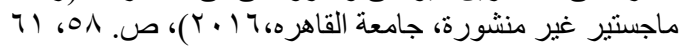

\section{Examples of the representation of Divine Wet Nurses from the temple of Isis at Philae $^{5}$}

The Mammisi of Philae, was built by Ptolemy III( Euergetes I) ${ }^{6}$, it is located on the left side of the main temple of Isis at Philae. The mammisi is surrounded on four sides by colums with capitals terminated in Hathor sistrums, with three rooms preceded by a naos. Isis and her son Horus are worshipped in the mammisi. The mammisi of Philae has many scenes representing the divine wet nurses Isis and Hathor, suckling their child Horus infront of the Ptolemaic King or the Roman emperor ${ }^{7}$.On the pillar of of the northeast corner (eightieth scene from the left), (fig.27) The Emperor Augustus is depicted offering Isis a tray of a laying Lion ${ }^{8}$. The lion holds a vase containing myrrh. The Emperor wears the royal nemus on his head and the short kilt, with the bull tail. Isis is sitting on the throne facing the king, suckling her child hand ${ }^{9}$.

\footnotetext{
${ }^{5}$ An island situated at the head of the first cataract, Philae is the largest island at the south end of the group of rocks that comprise the first cataract. Its Coptic name was ( Pilak) means the corner island or the end island. In ancient Egypt, Philae was considered the sacred island and domain of the goddess Isis. It was famous for its temple that is considered as one of the best preserved Ptolemaic temples; Arthur.E.P.Weigall, A Guide to the Antiquities,468; Alberto Carlo, Art and History of Egypt ( Florence, 2009), 180.

${ }^{6}$ Dee L.Clayman, BereniceII and the Golden Age of Ptolemaic Egypt (New York, 2004) 164.

${ }^{7}$ Giovanna Magi, Aswan, Philae, Abu simbel ( Florence, 1989), 62.

8

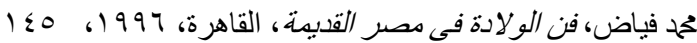

${ }^{9}$ Madeleine Peters, Philae le domaine d' Isis, 135.
} 


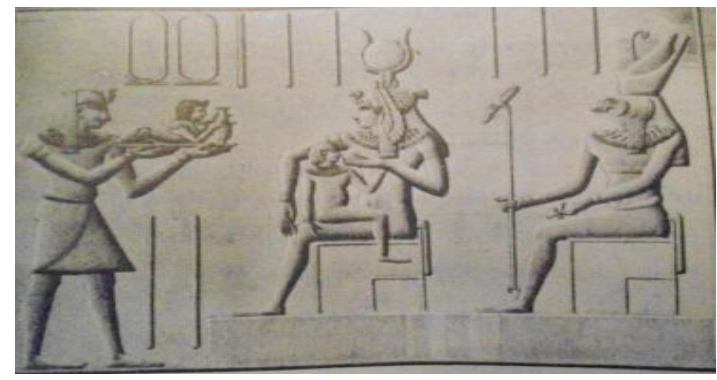

(fig.27)

The Emperor Augustus is offering a lion to Isis suckling Horus

Pillar northeast corner eightieth scene from the left (Mammisi of Philae)

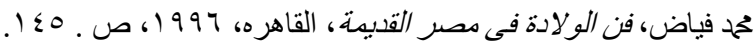

At Western wall (Mammisi of Philae) eighth scene from the south ${ }^{1}$, the emperor Tiberius, offering offering two small bouquets of flowers to the goddess

Isis who was represented suckling the young Harpocrate hand ${ }^{2}$.

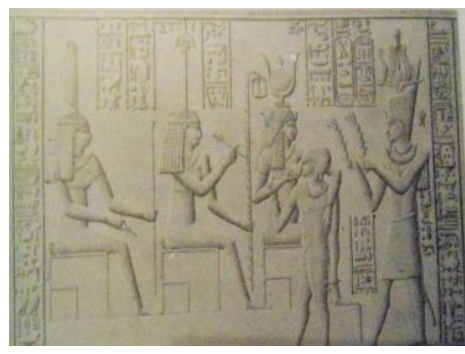

(fig.28)

Tiberius offering two small bouquets of flowers to the goddess Isis

Western wall (Mammisi of Philae) eighth scene from the south

زهير الثايب، وصف مصر لوحات الدولة القدبية ، (المجلد الأول)،

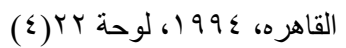

Examples of the representation of Divine wet nurse from the temple of Armant ${ }^{3}$

\footnotetext{
${ }^{1}$ Hermann Junker und Erich Winter, Das Geburtshaus des Tempels der Isis, 339.

${ }^{2}$ Madeleine Peters, Philae le domaine d' Isis, 145.
}

3 Armant $\theta_{\text {mmmin }} \backslash$ Greek Hermonthis, ancient Egypt pr- mntu, it was a significant regional centre of important temples and a major animal cult. It is now modern village of Armant, a tourist destination from Luxor. The temple of Armant lay to the north east of the modern village; Roger S. Bagnall and Dominic Rathbone, Egypt from Alexander to the early Christians An Archaeological and Historical guide (London, 2004), 207.
The mammisi of the temple of Armant, has a lot of scenes representing the divine

childbirth and the royal wet nurse, one of these reliefs represents the goddess Ritho ${ }^{4}$, the wife of god Mondu ${ }^{5}$ giving birth to the god Harphre (Horus the son) ${ }^{6}$ (fig.29). The goddess Rithio kneels on the ground, supported by three mid wives behind her, while another mid wife, represented in front of the goddess followed by two divine wet nurses ${ }^{7}$. The mid wife standing directly behind the goddess bend little towards Ritho. She holds the goddess's left arm with her left hand, while supporting the goddess's right arm with her right hand, trying to help her while giving birth ${ }^{8}$.

\footnotetext{
${ }^{4}$ Ritho: Egyptian goddess, she was adorned with the disks and horns of Hathor, and was particularly invoked at the accouchement of royalty; William Ricketts Cooper, An Archaic Dictionary: Biographical Historical and Mythology: From the Egyptian, Assyrian and Etruscan Monuments and Papyri (London, 1876), 464.

${ }^{5}$ Mondu: was the terrible and hostile form of the sun, when his rays strike like arrows and are sometimes fatal. He was specially worshipped at Hermonthis, depicted with the hawk's head. Goddess Ritho, with her husband Mondu and their son Harphre, together form the triad of the temple of Armant and the nome, in addition Ptolemy Caesarion (the son of Julius Cesar and of Cleopatra) was identified as the god Harphre; William Osburn, The Antiquities of Egypt: With a Particular Notice of Those that Illustrate the Sacred Scriptures (London, 1841), 140; Francois Lenormant, The student's manual of oriental history. A manual of the ancient history of the East to the commencement of the Median wars (London, 1869), 324.

${ }^{6}$ Hermann Heinrich Ploss Woman: An Historical Gynacological and Anthropological Compendium (London, 1935), 751.

7 Beth S. Gersh- Nesic, "Birth /Child Birth," in Encyclopedia of Comparative Iconography: Themes depicted in works of Art ed. Helene E. Roberts (London, 2013), 139.

8 Friedrich Weindler, Geburts und Wochenbettdarstellungen auf altägyptischen Tempelrelief (German, 1915), 29
} 


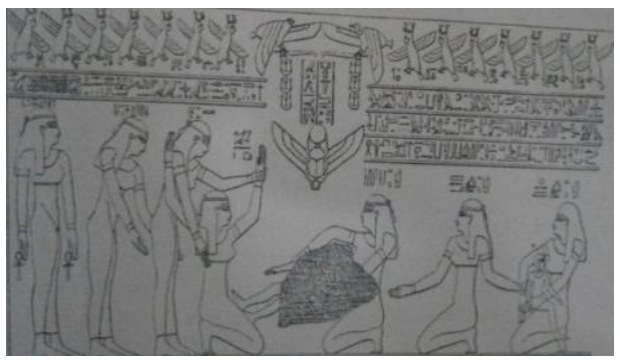

(fig.29)

Goddess Ritho depicted giving birth to child Harpre, who was suckled by divine wet nures-Mammisi of Armant

Friedrich Weindler, Geburts und Wochenbettdarstellungen auf altägyptischen Tempelrelief, Abbidung, 24

Another scene from the birth room of the mammisi of Armant. Divine wet nurses were represented in the scene, with two with cow's head ${ }^{1}$ (fig. 30). The goddess who has recently delivered a baby, represented sitting on a lion figured chair, suckling her new baby. She holds her right breast with her left hand, offering it to the child, while supporting his back with her right $\mathrm{arm}^{2}$.

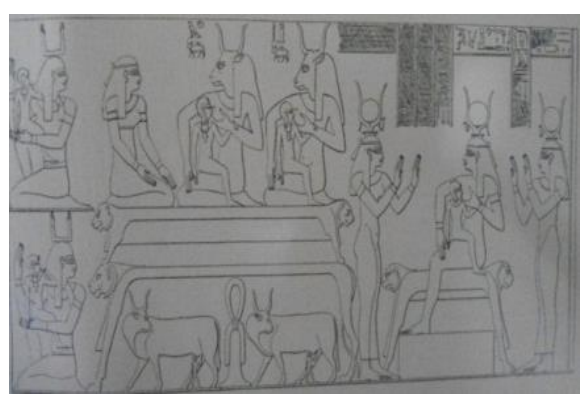

(fig.30)

Divine wet nurses suckling newborn god- Mammisi of Armant

Friedrich Weindler, Geburts und Wochenbettdarstellungen auf altägyptischen Tempelrelief, Abbidung 27

\footnotetext{
${ }^{1}$ Valerie Filds, Wet Nursing a History from Antiquity to the Present, 2.

2 Friedrich Weindler, Geburts und Wochenbettdarstellungen auf altägyptischen Tempelrelief, 34
}

\section{Examples of Representation of the Divine Wet Nurse Isis in Minor Arts}

A statue of Isis with her son, Horus, made of bright blue faience (fig.33) is dated to the Ptolemaic period (332- 30) B.C, preserved now in the Metropolitan museum of Art, (Pulitzer Bequest Fund, 1955, no. 55.121.5 twelfth Egyptian room). she is sitting, holding her left breast with her right arm, supporting her baby's back with her left arm. Horus is naked ${ }^{3}$.

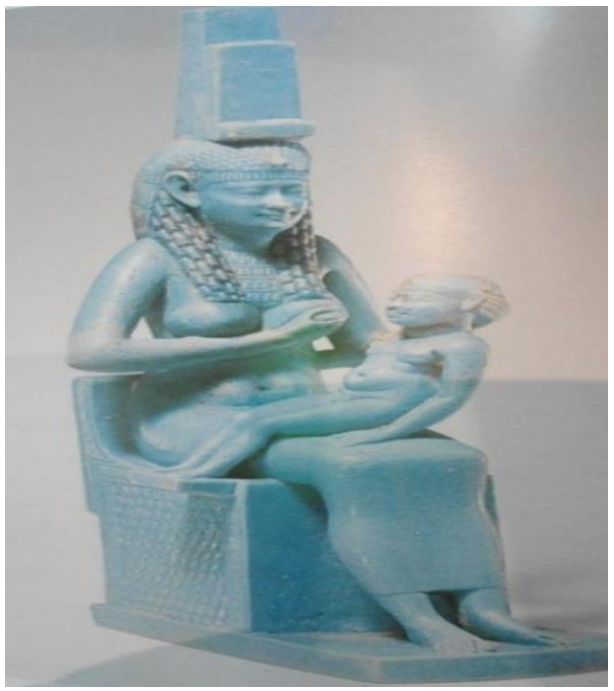

(fig.33)

Statue Isis preparing to nurse her infant Horus(Ptolemaic period)

The Metropolitan museum of Art, Pulitzer Bequest Fund, 1955, no.55.121.5, twelfth Egyptian room. James P. Allen, The Art of Medicine in Ancient Egypt The Metropolitan Museum of Art (New York, 2005), 35.

Bronze statue of goddess Isis nursing Horus (fig.34), dated to the early Ptolemaic period, preserved now in Museo Egizio Florence no.319. Isis is wearing the sun disc, between the two horns of the cow. On her head, she is wearing a wig on her head, with an uraeus and relief on the fore head. The goddess holds her left breast with her right

\footnotetext{
${ }^{3}$ James P. Allen, The Art of Medicine in Ancient Egypt The Metropolitan Museum of Art (New York, 2005), 34.
} 
hand, while with her left hand, she holds the little Horus who sits on her lap. ${ }^{1}$

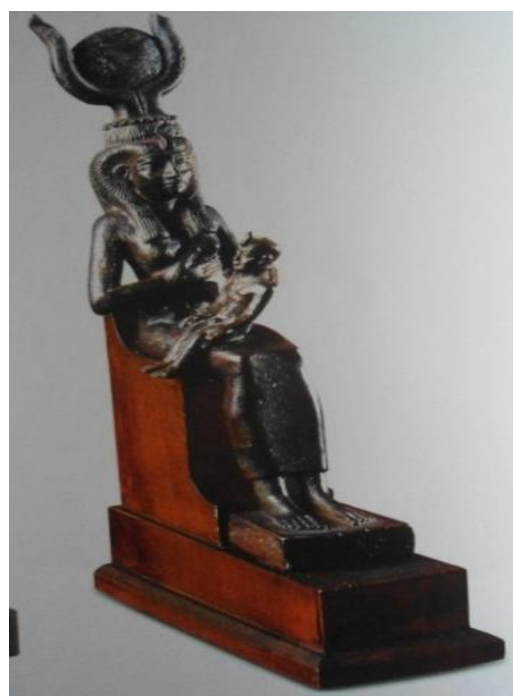

(fig.34)

Isis is nursing her infant Horus(Ptolemaic period) Museo Egizio Florence no.319

Maria Cristina Guidotti, " Estotuilla a de Isis Con Horus, " in Cleopatra Y La Fascinacion de Egipto ed. Marcello Florencia (Madrid, 2016): 23

\section{Conclusion}

- The profession of wet nurse was widely accepted as a social custom for high and ruling classes and most of wet nurses were recruited from lower societies.

- Reasons for using wet nurses were almost similar in most civilizations, the mother's death in childbirth was the most important and strong reason.

- The divine wet nurse was directly connected to the king in Pharaonic Egypt. She was one of the conditions that must be found to ensure the king divinity, by giving him the divine milk.

- In Pharaonic Egypt, the king was depicted suckling directly from the divine wet nurse, the king was either

\footnotetext{
${ }^{1}$ Maria Cristina Guidotti, " Estotuilla a de Isis Con Horus, " in Cleopatra Y La Fascinacion de Egipto ed. Marcello Florencia ( Madrid, 2016) : 232
}

standing or sitting on the lap of the wet nurse.

- Most of the divine wet nurses are shown suckling the king while standing, holding one of their breasts with one hand and giving it to the king.

- Royal wet nurses in the New kingdom are depicted more often.

- The statue of Hatshepsut seated on the lap of her wet nurse, and the depiction of Tutankhamun with his wet nurse, show how important this profession was especially in the royalty.

- Feeding bottles used by wet nurses were found in large number in Pharaonic Egypt, taking the shape of women with a child, while in ancient Rome and Greco-Roman Egypt, feeding bottles take the shape of pottery with a side mouth to feed the child.

- The two goddesses Hathor and Isis were the most famous divine wet nurses in Greco- Roman Egypt.

- Kings and emperors were rarely depicted suckled directly from the divine wet nurse, as this scene is not familiar in the Greco -roman Egyptian art.

- The king was depicted in the Ptolemaic and Roman Egyptian temple reliefs, in front of the wet nurses Isis and Hathor, who were suckling their son Horus. Horus was the representative of the king on earth. These scenes replace the scenes depicting the king suckled directly from the wet nurse in Pharaonic Egypt. 
- The Mammisi of the Egyptian Ptolemaic temples was the most place decorating with scenes that show the king standing in front of the goddess suckling her infant.

- Royal wet nurses were rarely depicted in the temple reliefs dated to the Ptolemaic Period, This may indicate that the role of royal wet nurse became less important in Greco-Roman Egypt, in comparison with the Pharaonic period.

- The representation of Isis lactons in terracotta statues and amults, show how this goddess was beloved by the public, as well as royal and wealthy people.

\section{Bibliography}

\section{Papyri}

1- The Oxyrhynchus papyri, 1-5, ed., by B.P.Grenfl \& A.S. Hunt \& others, London (Egypt Exploration society), 1898- 1986.

\section{Books and Articles}

1. Adolf Erman und Hermann Grapow, Wörterbuch der ägyptischen Sprache (Berlin, 1971).

2. Ahmed M. Mekawy Ouda, "The Golden pendant of Tutankhamun (JE. 61952). A new interpretation for the epithet Werethekau, ENIM 9(Cairo, 2016).

3. Aidan Dodson, " Thutmosis III: Family Man, " The Ostracon 15, 2 (summer, 2004) $1-8$.

4. Alberto Carlo, Art and History of Egypt (Florence, 2009).

5. Andrzej Cwiek, "Relief Decorations in the Royal Funerary Complexes of the Old kingdom: Studies in the Development scene content and Iconography" (MA thesis, University of Warsaw, 2003).

6. Angeliki Kosmopoulou, " Working Women: Female Professional on Classical Attic
Gravestones, " ABSA 96 (November, 2001) : 281- 319 .

7. Annette Bourland Huizenge, Moral Education for Women in the Pastoral and Pythagorean Letters (Boston, 2013).

8. Ann Meyering, " Selling Mother's milk: The Wet Nursing Business in France, 17151914, " J.ECON. HIST. 46(2), (January 1986).

9. Arthur E. P. Weigall, A Report on the Antiquities of lower Nubia (Oxford, 1907).

10. Audran Labrousse, Les Pyramides Des Reines Une Nouvelle Necropole A Saqqara (Washington, 1999).

11. Barbara S. Lesko, The Great Goddess of Egypt (Oklahoma, 1999).

12. Beth S. Gersh- Nesic, "Birth /Child Birth," in Encyclopedia of Comparative Iconography: Themes depicted in works of Art ed. Helene E. Roberts (London, 2013), 139-145.

13. Bouth C.H.F., "The Disadvantages of Employing Fallen Women as Wet Nurses," $B M J$, (April, 1860).

14. Bruno Halooua, Medicine in The Days of The Pharaohs (Cambridge, 2005).

15. Carolyn Graves Brown, Dancing for Hathor: Women in Ancient Egypt (London, 2010).

16. Cathrrine H. Roehrig, "Woman's Work: Some Occupations of Non Royal Women as depicted in Ancient Egyptian art, " in Mistress of the House Mistress of Heaven Women in Ancient Egypt ed. Anne K. Capel and Glenn E. Markoe ( New York, 1997) : 18-25.

17. Catharine Roehring, "The Statue of the Royal Nurse Sitre With her Nursling MaaTkare Hatshepsut, " in Egyptian Museum Collection around The World ed.Mamodouh Eldamaty (Cairo, 2000) : 100- 110.

18. Catharine H. Roherig, "The Two Tombs of Hatshepsut," in Hatshepsut From Queen to Pharaoh ed. Catharine H. Roehrig (London, 2005) 184- 267.

19. Charles J. Culling Worth, The Nurse's Companion . A Manual of General and Monthly Nursing ( London, 1876).

20. Dee L.Clayman, BereniceII and the Golden Age of Ptolemaic Egypt (New York, 2004). 
21. Charlotte Booth, The Ancient Egyptians for Dummies (London, 2011).

22. Detraci Regula, The Mysteries of Isis: Her Worship and Magic (London, 2001).

23. Edwards L.E.S, "Abusir," in Encyclopedia of the Archaeology of Ancient Egypt ed.Kathryn A. Bard (London, 1999), 97-99.

24. Emily Stevens and Thelma Patrick, "A History of Infant Feeding," JPE 18, 1(October 2009).

25. Erika Feucht, "Women," in The Egyptians ed. Sergio Dona Doni, (Chicago, 1997): 316-332.

26. Francois Lenormant, The student's manual of oriental history. A manual of the ancient history of the East to the commencement of the Median wars (London, 1869).

27. George Hart, The Routledge Dictionary of Egyptian Gods and Goddess (London, 2005).

28. Eugen Strouhal and Bretislav Vachola, The Medicine of the Ancient Egyptians (Cairo, 2014).

29. Francois Daumas, " La Structure de mammisi de Nectanebo a Dendara, "BIFAO L ( le caire, 1950) : 153- 155.

30. Frederck Brenk," Religion Under Trajan Plutarch, Resurrection of Osiris," in Sage and Emperor Plutarch, Greek Intellectuals and the Roman Power in the time of Trajan (98- 117 A.D) ed. Philip A. Stadter (Leuven, 2002) : 73-92.

31. Friedrich Weindler, Geburts- und Wochenbettdarstellungen auf altägyptischen Tempelrelief (German, 1915).

32. George Foucart, "Children (Egyptians)," in Encyclopedia of Religion and Ethics volume III ed. James Hastings (New York, 1910).

33. Gerald G, Briggs, Drugs in Pregnancy and Lactation: A Reference Guide to Fetal and Neonatal Risk (New York, 2001).

34. Gina Kolta, "Wet Nursing Boom," Science, New series 235(4790).

35. Giovanna Magi, Aswan, Philae, Abu Simbel (Florence, 1989).

36. Glenns S. Holland, Gods in the Desert Religions of the Ancient near East, (Maryland, 2009).

37. Gwendolyn Leick, A Dictionary of Ancient Near Eastern Architecture (London, 2002).

38. Harry W. Paul, Henri de Rothschild 18721947 Medicine and Theater (Florida, 2011).
39. Hennie j. Marsman, Women in Ugarit and Israel their Social and Religious Position in the Context of the Ancient Near East ( Boston, 2003).

40. Henry E. Sigerist, A History of Medicine: Early Greek, Hindu, and Persian, Volume II(New York, 1961).

41. Hermann Heinrich Ploss Woman: An Historical Gynacological and Anthropological Compendium (London, 1935)

42. Hermann Junker und Erich Winter, Das Geburtshaus des Tempels der Isis in Philä (Wein, 1965).

43. Hornblower, G. D, "Predynastic Figures of Women and Their Successors," JEA 15 (112), (May 1929).

44. Ian Shaw and Paul Nicholson, The British Museum Dictionary of Ancient Egypt (Cairo, 1995).

45. James P. Allen, The Art of Medicine in Ancient Egypt The Metropolitan Museum of Art (New York, 2005).

46. Janet Burnett Grossman, Looking at Greek and Roman Sculpture in Stone: A Guide to Terms, Styles, and Techniques (Los Angeles, 2003).

47. Janet Golden, A Social History of Wet nursing in America from Breast to Bottle (Cambridge, 1996).

48. Jan Quaegebeur, La naine et le bouquetin, ou, L'énigme de la barque en albâtre de Toutankhmamon (California, 2009).

49. John Baines and Jaromir Malek, Cultural Atlas of Ancient Egypt (New York, 2000).

50. John F. Nunn, Ancient Egyptian Medicine( Oklahoma, 2002)

51. John G. Raffensperger, Children Surgery a World Wide History (North Carolina, 2012).

52. Joyce E. Salisbury, Encyclopedia of Women in Ancient World (California, 2001).

53. Joycee Tyldesley, Daughters of Isis: Women of Ancient Egypt (London, 1995).

54. Julia L. Hairston, " The Economics of Milk and Blood in Alberti's Libri della famiglia: Maternal Versus Wet Nursing, " in Medieval and Renaissance Lactation ed. Jutta Gisela (London, 2013):185- 195.

55. Jutta Fisher, Griechisch-römische Terrakotten aus Ägypten (Tubingen, 1997). 
56. Kathryn. A. Bard, An Introduction to the Archaeology of Ancient Egypt (Florence, 2015).

57. Keth R. Bradley "Sexual Regulations in wet nursing Contracts from Roman Egypt," KLIO 62 (2), (February 1980):321- 325.

58. Labib Habachi, " King Nebhepetre Menthuhotep : His Monuments, Place in History, Deification and Unusual Representation in the Forms of Gods, " MDAIK 19 (Kairo, 1963):16-52.

59. László Török, Hellenistic and Roman Terracotta from Egypt (Roma, 1914).

60. Lionel Rose, The Massacre of The Innocents: Infanticide in Britain 18001939(New York, 1986).

61. Madeleine Peters, Philae le domaine d' Isis, (Paris, 1997).

62. Manfred Lurker, The Routledge Dictionary of Gods Goddess Devils and Demons (London, 1984).

63. Margret R. Bunson, Encyclopedia of Ancient Egypt (New York, 2002).

64. Maria Cristina Guidotti, " Estotuilla a de Isis Con Horus, " in Cleopatra Y La Fascinacion de Egipto ed. Marcello Francone (Madrid, 2016) : 232-233.

65. Marianne Eaton Krauss, The Unknown Tutankhamun (London, 2015).

66. Melinda Harlwig, The Tomb Chapel of Menna (TT69) The Art, Culture and Science of Painting in an Egyptian Tomb ed. Melinda Harlwig (Cairo, 2013).

67. Melitta Weiss Adamson, "Baby food in the Middle Ages," in Nurture: Proceeding of the Oxford Symposium on Food ed. Richard Hosking (Bristol, 2004): 1- 12.

68. Mohamed Abd Ellatef Hassan, " The Scenes of the Archaeological Objects of Suckling in Ancient Egypt from the Old Kingdom till the Greco- Roman Period" ( MA thesis, University of Alexandria, 2014).

69. Natalie Rosen, "The Milk Relation Ship: The Evolution and Significance of Wet nurses" ( MA thesis, university of Pennsylvania, 2013).

70. Norman De Garis, The Tomb of Ken-Amun at Thebes Vol. II, (New York, 1935).

71. Pat Remler The Egyptian Mythology A to $Z$ (New York, 2010).
72. Patrick E. MC Govern, Ancient Wine: The Search for the origins of Viniculture (New Jersey, 2003).

73. Paul Graindor, Terres cuites de l'Egypte gréco-romaine (Belgique, 1939).

74. Prisse D'Avennes, Atlas of Egyptian Art (Cairo, 2007.

75. Prophecy Cloes, The Shadow of the second Mother: Nurses and Nannies in the theories of infant development (London: 2015).

76. Regine Schulz and Houring Sourouzian, "The Temples Royal Gods and Divine Kings," in Egypt the World of the Pharaohs ed. Regine Schulz (Cairo, 2002): 153- 215.

77. Roger s. Bangnall and Dominic W. Rathbone, Egypt from Alexandria to the Early Christians: An Archaeological and Historical Guide (London, 2004).

78. Rosalie David, A Guide to Religious Ritual at Abydos (Warminster, 1981).

79. Rosalie E.David, A Biographical Dictionary of Ancient Egypt( London, 1992).

80. Samir Arora and Cheryal Mcjunkin, " Major Factors Influencing Breastfeeding Rates: Mothers Perception of Father's Attitude and Milk Supply, " Pediatrics 106(5), (November, 2000).

81. Sarah Franklin, Women and Slavery in Nineteenth- century Colonial Cuba (New York, 2012).

82. Sigrid Hodel Hoenes, Life and Death in Ancient Egypt Scenes from private tombs in New kingdom Thebes (London, 2000).

83. Stephanie Lynn Budin, Images of Woman and Child Reconsidering Fertility, Maternity, and Gender in the Ancient World (New York, 2011).

84. Suzanna Dixon, The Roman Mother (London, 1988).

85. Sylvie Cauville, Le Temple de Dendera (Le Caire, 1990).

86. Sylvie Cauville, "Dendara," in Encyclopedia of the Archaeology of Ancient Egypt ed. Kathyrn a.Bard (London, 1999) : 252-254.

87. Thomas Bull, The Maternal Management of Children in Health and Disease (London, 1840).

88. Tran Tam Tinh, Isis Lactons Corpus des Monuments Greco-Romains d'Isis allaitant Harpocrate (Nether land, 1973). 
89. Urs Winter, Frau Und Gottin: Exegetische Und Ikonographische Studien Zum Weiblichen Gottesbild im Alten Israel Und in Dessen Umwelt (Fribourg,1983).

90. Valerie Fildes, Wet Nursing a History from Antiquity to the Present (New York, 1988).

91. William Matthew, Ancient Egypt (Michigan, 1932.

92. William Ricketts Cooper, an Archaic Dictionary: Biographical Historical and Mythology: From the Egyptian, Assyrian and Etruscan Monuments and Papyri (London, 1876).

93. William R. Osborne, "The Tree of Life in Ancient Egypt and the Book of Proverbs," JANER 14 (June, 2014): 114- 139.

94. William Stevenson Smith, A History of Egyptian Sculpture and Paintings in the Old kingdom (London, 1949)

95. Zahi Hawas, Wonders of the Horus Temple The Sound and Light of Edfu (Cairo, 2010).

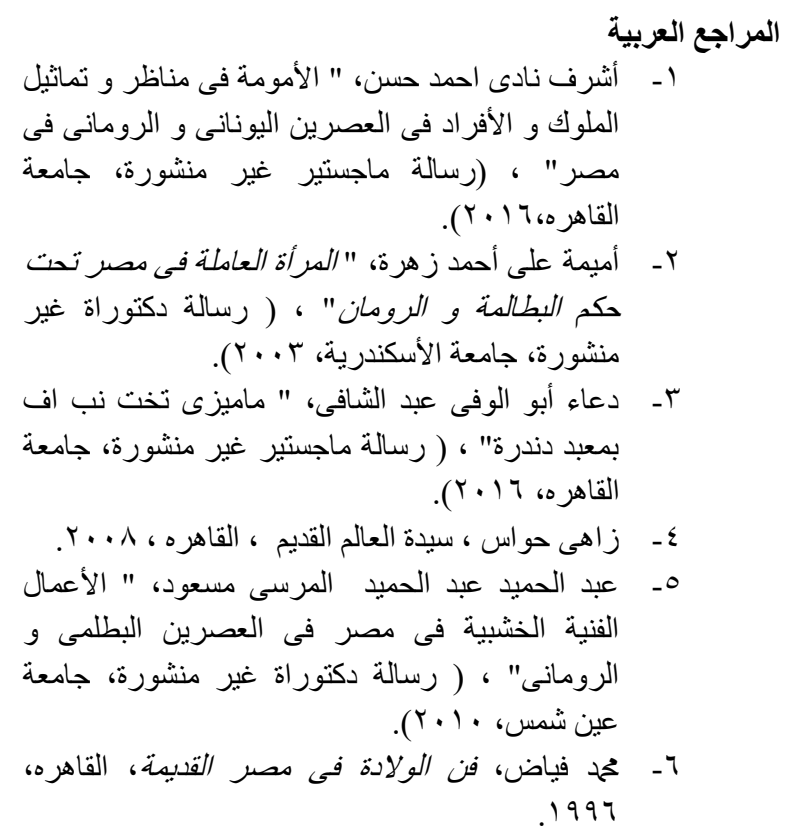

